\title{
PENINGKATAN KEMAMPUAN MENULIS TEKS DESKRIPSI DENGAN MEDIA GAMBAR BERSAMBUNG
}

\author{
Budiyono \\ budi yono19@gmail.com \\ SMP Negeri 19 Kota Bengkulu
}

\begin{abstract}
Abstrak
The objective of this research was to know the improvement of students' ability in writing descriptive text by using picture series media. The subject of the research was students on class $H$ at VII (seven) Junior High School 19 Bengkulu City, there were 23 students. The form of this research was a classroom action research. The data of this research were gathered from the descriptive writing test and analyzed by using descriptive analysis. The result showed that there are an improvement of students' ability in writing descriptive text by using picture series media on class H at VII (seven) Junior High School 19 Bengkulu City. It can be seen from the writing result on cycle I that students' average score 70 (enough) and increased with 76,04 (good) after repaired on cycle II, then increased again after repaired on cycle III with 86,17 (very good).
\end{abstract}

Kata Kunci: writing skills, picture series media.

\section{PENDAHULUAN}

Pengajaran keterampilan Bahasa Indonesia di sekolah meliputi empat aspek keterampilan berbahasa yang harus dikuasai oleh siswa. Keempat aspek tersebut adalah aspek mendengarkan, berbicara, membaca, dan menulis. Dari keempat aspek keterampilan berbahasa itu, satu aspek yang sangat penting dan berperan dalam pengembangan budaya, hasil cipta, rasa, dan karsa manusia adalah aspek menulis.

Menulis merupakan suatu keterampilan berbahasa yang dipergunakan untuk berkomunikasi secara tidak langsung, tidak secara tatap muka dengan orang lain. Menulis merupakan suatu kegiatan yang produktif dan ekspresif. Dalam kegiatan menulis ini, penulis haruslah terampil memanfaatkan grafologi, struktural bahasa, dan kosakata. Keterampilan menulis ini tidak akan datang secara otomatis, tetapi harus melalui latihan dan praktik yang teratur (Tarigan, 2008: $3)$.

Teks adalah satuan bahasa yang digunakan sebagai ungkapan-ungkapan suatu kegiatan sosial baik secara lisan maupun tulis dengan struktur berpikir yang lengkap. Definisi di atas, menuntun pada pencirian teks yang wujudnya dapat berupa bahasa yang dituturkan atau dituliskan atau juga bentuk-bentuk sarana lain yang digunakan untuk menyatakan apa saja yang dipikirkan, misalnya jenis teks label atau multimodal. Itu sebabnya pula, kata-kata atau kalimat-kalimat lepas yang tidak memiliki konteks situasi yang mungkin dituliskan di papan tulis bukanlah teks. Teks deskripsi memiliki tujuan sosial untuk menggambarkan sesuatu objek/benda secara individual berdasarkan ciri fisiknya. Gambaran yang dipaparkan dalam teks ini haruslah yang 
spesifik menjadi ciri keberadaan objek yang digambarkan. Oleh karena itu, teks deskripsi memiliki struktur berpikir peryataan umum, uraian bagian-bagian (Mahsun, 2014: 28).

Keterkaitan antara media pembelajaran dengan tujuan, materi, metode, dan kondisi pembelajaran, harus menjadi perhatian dan pertimbangan pengajar untuk memilih dan menggunakan media dalam proses pembelajaran di kelas, sehingga media yang digunakan lebih efektif dan efisien untuk mencapai tujuan pembelajaran. Sebab media pembelajaran tidak dapat berdiri sendiri, tetapi terkait dan memiliki hubungan secara timbal balik dengan empat aspek tersebut. Dengan demikian, alat-alat, sarana, atau media pembelajaran yang digunakan harus disesuaikan dengan empat aspek tersebut, untuk mencapai tujuan pembelajaran secara efektif dan efisien.

$$
\text { Gambar sangat penting }
$$

digunakan dalam usaha memperjelas pengertian pada peserta didik. Sehingga dengan menggunakan gambar peserta didik dapat lebih memperhatikan terhadap benda-benda atau hal-hal yang belum pernah dilihatnya yang berkaitan dengan pelajaran. Gambar dapat membantu guru dalam mencapai tujuan instruksional karena gambar termasuk media yang mudah dan murah serta besar artinya untuk mempertinggi nilai pengajaran. Karena gambar, pengalaman dan pengertian peserta didik menjadi lebih luas, lebih jelas dan tidak mudah dilupakan serta lebih konkret dalam ingatan dan asosiasi peserta didik.

Media pembelajaran dapat dipahami sebagai segala sesuatu yang dapat menyampaikan dan menyalurkan pesan dari sumber secara terencana sehingga tercipta lingkungan belajar yang kondusif dimana penerimanya dapat melakukan proses belajar secara efisien dan efektif. Alasan utama para guru tidak menggunakan atau menghadirkan gambar dalam proses pembelajaran adalah "tidak bisa menggambar". Alasan ini tampaknya hanya untuk menutupi dirinya yang kurang kreatif atau malas karena sudah enjoy dengan pola yang selama ini dilakukan (metode ceramah) dan lain-lain. Bahkan ia lupa kalau dirinya pernah belajar menggambar dan mewarnai pada saat duduk di sekolah dasar bahkan di taman kanak-kanak (Munadi, 2008: 86).

Sebagai guru bahasa dan sastra Indonesia di kelas VII SMP Negeri 19 Kota Bengkulu. Peneliti selama melaksanakan pembelajaran sering mengalami berbagai masalah, terutama pada pembelajaran menulis teks deskripsi, masih banyak siswa mengalami kesulitan dalam menyusun atau menulis teks deskripsi. Kesulitan tersebut adalah: (1) Siswa belum mampu menulis teks deskripsi yang panjangnya 12-15 kalimat dengan bahasa yang baik dan benar; (2) Siswa belum mampu menulis teks deskripsi dengan struktur deskripsi umum dan deskripsi bagian; (3) Siswa belum mampu menulis teks deskripsi dengan ejaan yang benar. Hasil belajar yang diperoleh siswa masih rendah yaitu dibawah KKM. KKM yang ditentukan untuk pelajaran menulis teks deskripsi ini adalah 75.

Penelitian yang pernah dilakukan oleh peneliti lain yang relevan berjudul "Peningkatan Kemampuan Menulis Karangan Deskripsi Siswa Kelas IX SMP Negeri 01 Lebong Selatan dengan Media Gambar" menyarankan, perlu kiranya penerapan media gambar sebagai media pembelajaran di sekolah-sekolah, untuk 
meningkatkan kemampuan menulis karangan deskripsi pada siswa khususnya dan untuk meningkatkan pemahaman siswa akan materi pada umumnya (Haryanto, 2013: 56).

Berdasarkan kenyataan di atas, penulis akan melakukan penelitian dengan menggunakan media gambar bersambung dalam pembelajaran menulis teks deskripsi. Karena dengan menggunakan media gambar bersambung tersebut diharapkan dapat merangsang aktivitas dan kreativitas siswa mengembangkan tulisan teks deskripsi berdasarkan media gambar bersambung yang disajikan oleh guru.

Penelitian ini akan menggunakan media gambar bersambung untuk mempermudah siswa dalam memperbaiki hasil menulis teks deskripsi siswa. Yang harus diperbaiki adalah: isi, struktur, dan ejaan. Pembelajaran menulis ini dalam kurikulum 2013 terdapat di kelas VII KI4. Mencoba, mengolah, dan menyaji dalam ranah konkret (menggunakan, mengurai, merangkai, memodifikasi, dan membuat) dan ranah abstrak (menulis, membaca, menghitung, menggambar, dan mengarang) sesuai dengan yang dipelajari di sekolah dan sumber lain yang sama dalam sudut pandang/teori. KD4.1 Menyusun teks hasil observasi, tanggapan deskriptif, eksposisi, eksplanasi, dan cerita pendek sesuai dengan karakteristik teks yang akan dibuat baik secara lisan maupun tulisan.

Berdasarkan KI dan KD di atas kegiatan yang akan dilakukan siswa adalah mengobservasi media gambar bersambung yang penulis sajikan kemudian siswa akan mendeskripsikan hasil observasi tersebut dalam bentuk menulis teks deskripsi. Pelaksanaan perbaikan menulis teks deskripsi akan dilakukan tiga siklus dengan media gambar bersambung, agar kemampuan menulis teks deskripsinya dapat meningkat.

Berdasarkan pada beberapa pernyataan di atas dan pengalaman di lapangan bahwa pemahaman siswa dalam menulis teks deskripsi masih rendah, terutama di SMP Negeri 19 Kota Bengkulu. Maka dari itu penulis tertarik untuk melakukan penelitian dengan judul "Peningkatan Kemampuan Menulis Teks Deskripsi Siswa Kelas VII SMP Negeri 19 Kota Bengkulu dengan Media Gambar Bersambung".

Berdasarkan latar belakang di atas rumusan penelitian ini adalah bagaimanakah peningkatan kemampuan menulis teks deskriptif dengan menggunakan media gambar bersambung pada siswa kelas VII SMP Negeri 19 Kota Bengkulu?

Kesulitan yang dihadapi oleh siswa dalam keterampilan menulis antara lain kurang mampu mengembangkan ide-ide, penggunaan tanda baca, dan ketidakteraturan alur yang dituangkan sehingga teks tidak berjalan dengan baik.

Cara memecahkan masalah penelitian menulis teks deskripsi dilakukan dengan menggunakan media gambar bersambung, dengan aspek penilaian yang meliputi aspek isi, struktur teks deskripsi, dan ejaan.

Ruang lingkup penelitian ini yaitu pada menulis teks deskripsi dengan menggunakan media gambar bersambung bertema Pengenalan Budaya Indonesia dengan subtema Fungsi Pasar Bagi Kehidupan Masyarakat, sedangkan aspek yang dinilai meliputi 
aspek isi, struktur teks deskripsi, dan ejaan.

Tujuan penelitian ini untuk mengetahui peningkatan kemampuan menulis teks deskripsi pada siswa kelas VII SMP Negeri 19 Kota Bengkulu dengan media gambar bersambung.

Manfaat yang diharapkan dari penelitian ini adalah: (i) Dapat dijadikan tolak ukur bagi guru bahasa Indonesia untuk memilih media yang tepat dalam pembelajaran; (ii) Dapat mengetahui kemampuan menulis teks deskriptif siswa kelas VII SMP Negeri 19 Kota Bengkulu; (iii) Dapat memberikan masukan dalam penyampaian materi pembelajaran yang sesuai dengan perkembangan kognitif siswa; (iv) Penelitian ini memberikan informasi mengenai peningkatan kemampuan menulis teks deskriptif siswa kelas VII SMP Negeri 19 kota Bengkulu; (v) Siswa diharapkan lebih termotivasi untuk belajar; (vi) Kemampuan siswa dalam menulis teks akan lebih meningkat.

\section{METODE PENELITIAN}

Penelitian ini merupakan penelitian tindakan kelas (PTK). Secara umum dapat dikatakan bahwa PTK merupakan suatu kajian yang bersifat reflektif sebagai upaya untuk memperbaiki keadaan (proses) atau memecahkan masalah yang dihadapi, dan juga mencari kebenaran secara praktis. Berkaitan dengan pembahasan secara khusus bahwa PTK ialah kegiatan perbaikan, peningkatan, dan perubahan pembelajaran ke arah yang lebih baik guna tercapainya tujuan pembelajaran yang optimal. Bentuk kajian ini merupakan kajian reflektif untuk memperoleh atau meningkatkan kualitas proses belajar - mengajar (Susetyo, 2010: 89).

Penelitian tindakan kelas yang selanjutnya disebut PTK adalah penelitian yang mengangkat masalahmasalah yang aktual yang dilakukan oleh para guru yang merupakan pencermatan kegiatan belajar yang berupa tindakan untuk memperbaiki atau meningkatkan praktik pembelajaran di kelas secara lebih profesional (Taniredja, 2010: 16).

PTK adalah penelitian yang dilakukan oleh pendidik/calon pendidik di dalam kelasnya sendiri secara kolaboratif/partisipatif untuk memperbaiki kinerja pendidik menyangkut kualitas proses pembelajaran, dan meningkatkan hasil belajar peserta didik, baik dari aspek akademik maupun non akademik, melalui tindakan reflektif dalam bentuk siklus (Tampubolon, 2014: 19).

Dari pendapat yang dikemukakan di atas, maka jenis penelitian ini adalah penelitian tindakan kelas (PTK) dengan langkah perencanaan, tindakan, pelaksanaan tidakan, observasi, dan merefleksikan tindakan berdama orang lain atau bersifat kolaboratif untuk meningkatkan mutu pendidikan, memecahkan masalah yang dihadapi dan juga mencari kebenaran proses belajarmengajar dalam bentuk siklus (daur ulang).

Penelitian ini dilakukan di SMP Negeri 19 kota Bengkulu tahun pelajaran 2015/2016. Penelitian dilakukan di kelas VII, karena pada kelas VII materi menulis teks deskripsi dimulai. Penelitian dimulai dari bulan Januari sampai dengan bulan April 2016. Kegiatan yang dilakukan peneliti dan kolaborator adalah menyusun RPP, alat evaluasi dan persiapan pembelajaran menulis teks 
deskripsi dengan media gambar bersambung.

Subjek penelitian ini siswa kelas VII SMP Negeri 19 Kota Bengkulu. Siswa ini berjumlah 23 orang, yaitu terdiri dari 16 orang siswa laki-laki dan 7 orang siswa perempuan.

Data penelitian ini adalah tulisan teks deskripsi (data kuantitatif) siswa kelas VII SMP Negeri 19 Kota Bengkulu berdasarkan hasil observasi (data kualitatif) dalam proses pembelajaran dengan menggunakan media gambar bersambung.

Sumber data penelitian ini adalah siswa kelas VII SMP Negeri 19 Kota Bengkulu tahun pembelajaran 2016 semester genap.

Penelitian tindakan kelas ini dilaksanakan tiga siklus. Diharapkan dengan dilaksanakan tiga siklus sudah memberikan kejelasan pelaksanaan tindakan yang diberikan menunjukkn hasil yang maksimal.

Tampubolon (2014: 29) menyatakan bahwa prosedur penelitian tindakan kelas meliputi:

1. Pra Penelitian (Refleksi Awal)

Pra penelitian merupakan refleksi awal, yaitu sebelum penelitian tindakan siklus dilaksanakan, dilakukan kegiatan sebagai berikut: (i) Menyusun format pengumpulan data objektif sekolah; (ii) Menyusun kisi-kisi soal dan instrumen penilaian teks awal; (iii) Mengumpulkam data objektif sekolah dengan menggunakan format pra penelitian; (iv) Melaksanakan penelitian/tes awal terhadap materi yang sudah dibelajarkan oleh guru; (v) Menganalisis data objektif sekolah dan hasil tes untuk dimanfaatkan dalam perencanaan tindakan serta pembahasan hasil.
2. Penelitian Tindakan Kelas

Berdasarkan hasil evaluasi analisis data pra penelitian dan hasil tes awal serta diskusi tim kolaborasi dapat merancang perangkat pembelajaran yang akan disikluskan. Berdasarkan rancangan perangkat pembelajaran tersebut dapat disusun perencanaan tindakan untuk siklus pertama berikut ini.

1) Perencanaan Tindakan

Menyusun perangkat pembelajaran yang akan dilaksanakan meliputi komponen sebagai berikut:

(a) Silabus Mata Pelajaran

Silabus mata pelajaran yang akan disikluskan.

(b) Program Semester

Program semester sangat diperlukan untuk menyusun materi ajar yang akan disikluskan, karena bila penelitian semester ganjil, maka materi ajar (Kompetensi Dasar atau KD) harus semester ganjl.

(c) Rencana Pelaksanaan Pembelajaran (RPP)

RPP pada siklus pertama dan seterusnya meliputi SK, KD/Indikator, Nilai-nilai karakter bangsa, tujuan pembelajaran, materi ajar, strategi pembelajaran (pendekatan, model, dan metode pembelajaran), langkahlangkah kegiatan pembelajaran, alat / media / sumber, dan penilaian.

(d) Lembar Bahan Ajar (Materi Pembelajaran)

Mendeskripsikan secara singkat materi ajar atay materi pembelajaran.

(e) Lembar Kegiatan Siswa (LKS) 
LKS tentang topik / judul, tujuan kegiatan, alat / media / bahan yang digunakan, langkahlangkah kegiatan (prosedur), matriks pengamatan dan pertanyaan.

(f) Media / alat / sumber belajar

2) Pelaksanaan Tindakan

(a) Mengkondisikan ruang belajar bagi siswa dan kolaborator.

(b) Peneliti melaksanakan pembelajaran dan / atau penelitian dengan menggunakan perangkat pembelajaran sesuai skenario pembelajaran dalam RPP melalui tahapan kegiatan awal serta kegiatan inti yaitu keiatan eksplorasi, kegiatan elaborasi, dan kegiatan konfirmasi.

(c) Melaksanakan penilaian atau tes siklus pertama.

(d) Kegiatan akhir untuk menarik simpulan, pemberian tugas, dan informasi materi pembelajaran lebih lanjut.

3) Observasi

(a)Secara simultan pada saat pembelajaran berlangsung, kedua kolaborator melakukan penilaian atas pelaksanaan pembelajaran dikelas dengan menggunakan instrumen penilaian pelaksanaan pembelajaran di kelas.

(b) Kemudian observer bersama peneliti melakukan pengumpulan data tentang motivasi belajar siswa dengan menggunakan angket.

(c) Melakukan observasi keaktifan siswa secara berkelompok.
4) Refleksi

Refleksi hasil evaluasi analisis data penelitian siklus I tentang aspek/Indikator berikut:

(a) Penilaian kualitas proses pembelajaran di kelas.

(b) Motivasi belajar siswa.

(c) Hasil belajar secara individu dan klasikal.

Hasil evaluasi dan diskusi tim kolaborasi dapat direfleksikan dalam bentuk rekomendasi untuk dilanjutkan ke siklus berikutnya setelah RPP diperbaiki agar sesuai dengan rancangan pembelajaran di kelas (Indikator 2, materi pembelajaran, LKS, Instrumen Penilaian, dan lain-lain), namun pendekatan, model, dan metode pembelajaran adalah tetap.

Tampubolon (2014: 31) teknik pengumpulan data dalam penelitian ini adalah berupa observasi, tes, dan studi dokumentasi.

1. Observasi

a. Penilaian pelaksanaan proses pembelajaran di kelas. Tim kolaborator yang terdiri dari 2 orang (guru dan mahasiswa) melakukan penilaian berdasarkan observasi terhadap pelaksanaan pembelajaran yang dilakukan oleh peneliti. Penilaian pelaksanaan pembelajaran diberikan dalam bentuk centang atauceklis pada instrumen yang sama.

b. Melakukan pengisian angket tentang motivasi belajar oleh siswa setelah pembelajaran selesai. 
2. Penilaian

Melaksanakan penilaian (tes untuk tiga submateri ajar) dengan bentuk soal esai yang berbeda setiap siklus untuk mengukur ketercapaian indikator-indikator yang disampaikan oleh peneliti, sekaligus mengukur nilai kompetensi dasar (KD)

\section{Studi Dokumentasi}

Melaksanakan pengumpulan data objektif sekolah melalui format penelitian.

Dari pendapat yang dikemukakan di atas, maka pengumpulan data dilakukan dengan teknik tes. Teknik tes keterampilan menulis teks deskripsi dengan media gambar bersambung dilakukan untuk memperoleh data keterampilan menulis karangan deskripsi. Dalam tes, siswa diminta menulis teks deskripsi dengan memperhatikan aspek kebahasaan yaitu isi,organisasi, kosakata, dan penulisan.

\section{HASIL DAN PEMBAHASAN}

Penelitian ini dilaksanakan pada semester genap di kelas VII H SMP Negeri 19 Kota Bengkulu tahun pelajaran 2015/2016. Penelitian ini berlangsung dalam jangka waktu empat bulan, dari tanggal 25 Januari sampai 30 April 2016.

Siswa kelas VII H SMP Negeri 19 Kota Bengkulu, berjumlah 23 siswa terdiri dari 16 orang siswa laki-laki dan 7 orang siswa perempuan. Jumlah jam pelajaran per minggu 5 jam dibagi dua pertemuan. Satu jam pelajaran 40 menit.

Di kelas VII SMP Negeri 19 Kota Bengkulu yang mengajar mata pelajaran Bahasa Indonesia tiga orang. Penulis mengajar mata pelajaran Bahasa Indonesia di kelas VII sudah delapan tahun. Dalam penelitian ini, penulis dibantu dua orang guru Bahasa
Indonesia sebagai kolaborator, yaitu Tarmizi, M.Pd. dan Yarni, M.Pd.

Penelitian tindakan kelas ini dilaksanakan dalam tiga siklus yang sudah dianggap mampu memenuhi target sehingga mencapai hasil yang maksimal dan yang diharapkan.

1. Deskripsi Data Siklus I

a. Tahap Perencanaan

Tindakan Siklus I

Setelah dilakukan analisis pada prasiklus, peneliti dan kolaborator memfokuskan untuk mengatasi masalah yang ditemukan pada saat observasi prasiklus. Pada tahap observasi prasiklus ditemukan bahwa (1) Siswa belum mampu menuangkan buah pikiran dalam bentuk tulisan teks deskripsi berdasarkan isi struktur dan ejaan, (2) pada proses pembelajaran guru kurang aktif memilih metode-metode (penggunaan media) pembelajaran yang akan diterapkan.

Berdasarkan masalah tersebut guru dibantu kolaborator membimbing siswa menulis teks deskripsi secara mandiri. Tema yang akan siswa tulis sebagai teks deskripsi adalah "Fungsi Pasar bagi Kehidupan Masyarakat". Agar dapat menulis teks deskripsi dengan baik siswa mengerjakan tugas-tugas berikut ini.

Tugas 1 Mencari dan Mengidentifikasi Teks Deskripsi

Sebelum menulis teks deskripsi tentang "Fungsi Pasar bagi Kehidupan Masyarakat", Siswa perlu membuat langkah-langkah berikut.

1. Mengumpulkan data tentang pasar.

2. Mengidentifikasi pasar yang berkaitan dengan kehidupan sehari-hari.

3. Menulis deskripsi umum yang berkaitan dengan pasar. 
4. Menulis deskripsi bagian yang berkaitan dengan pasar tersebut.

5. Memikirkan bahwa pasar itu berguna bagi pariwisata.

6. Mengutip pendapat bahwa pasar menggambarkan budaya masyarakat tertentu.

Tugas 2 Menulis Teks Deskripsi

Setelah data tentang penulisan teks deskripsi siswa kumpulkan: Guru menugaskan siswa menulis teks deskripsi berdasarkan pengembangan data (kerangka karangan yang telah disusun). Guru memberikan rambu-rambu penilaian. Siswa melakukan penulisan teks deskripsi tentang pasar.

b. Tahap Pelaksanaan Tindakan Siklus I

Proses pelaksanaan tindakan kelas siklus I dua kali pertemuan yang berlangsung selama $2 \times 40$ menit yang dilaksanakan pada hari Senin, 07 Maret 2016 dan hari Selasa , 08 Maret 2016.

1) Pertemuan Pertama $(2 \times 40$ menit)

Proses tindakan pada siklus I difokuskan pada pembelajaran pra menulis, yang merupakan tahap awal menulis. Tahap ini bertujuan untuk mengarahkan pandangan dan memberikan kerangka berpikir terhadap siswa sehingga objek yang ditulis teridentifikasi dengan jelas. Berdasarkan dengan tujuan tersebut, maka pembelajaran pada siklus I difokuskan pada tahap mendeskripsikan gambar pasar.

Pada pertemuan pertama ini, Siswa dibagi dalam lima kelompok. Setelah kelompok dibagi kemudian guru menyuruh siswa berdiskusi mendeskripsikan media pembelajaran tindakan I berupa gambar pasar pada umumnya. Berikut ini tugasnya.
Susunlah tulisan teks deskripsi secara berkelompok! Setiap kelompok 45 orang. Ikutilah langkah-langkah berikut untuk menulis teks deskripsi! Buatlah identifikasi tentang pasar atau yang kamu ketahui. Deskripsikan bagian umum, kemudian deskripsikan bagianbagiannya bersama kelompokmu.

Sementara siswa berdiskusi, guru berkeliling mendatangi kelompok kalaukalau ada siswa yang masih mengalami kesulitan dalam mengerjakan tugasnya. Selama mengerjakan tugasnya, guru dibantu satu orang guru sebagai kolaborator, untuk memperhatikan dan mencatat aktivitas siswa di dalam lembaran observasi.

Setelah tepat pada waktu yang ditentukan, siswa dimita untuk mengumpulkan tugasnya. Kemudian guru menyuruh siswa untuk membaca hasil tulisan teks deskripsinya di depan kelas. Kelompok yang lain menanggapi yang dideskripsikan.

2) Pertemuan Kedua ( $2 \times 40$ menit) Proses pelaksanaan tindakan I pertemuan kedua berlangsung pada hari Selasa, 08 Maret 2016, yang merupakan kelanjutan dari pertemuan pertama. Sebelum siswa melakukan tugas menulis teks deskripsi dengan media gambar bersambung yang digunakan sebagai tes siklus I, guru memberikan arahan tentang rambu-rambu penilaian. Di samping itu penulis memberikan penjelasan tentang tugas yang akan dilaksanakan oleh siswa. Setiap tugas yang diserahkan oleh siswa kepada guru akan dicatat dan diberi nilai. Adapun rambu-rambu penilaian adalah sebagai berikut:

a) Siswa menyerahkan tugas dengan tepat waktu, kemudian hasil teks deskripsi yang didapatnya setelah 
dikoreksi 86-100 akan diberi nilai baik sekali (BS).

b) Siswa menyerahkan tugas dengan tepat waktu, kemudian hasil teks deskripsi yang didapatnya setelah dikoreksi 71-85 akan diberi nilai baik (B).

c) Siswa menyerahkan tugas dengan tepat waktu, kemudian hasil teks deskripsi yang didapatnya setelah dikoreksi 56-70 akan diberi nilai cukup (C).

d) Siswa menyerahkan tugas dengan tepat waktu, kemudian hasil teks deskripsi yang didapatnya setelah dikoreksi $\leq 55$ akan diberi nilai kurang (K).

Selanjutnya, guru memberikan tugas kepada siswa untuk menulis teks deskripsi sebagai tes tindakan siklus I, waktu yang disediakan guru untuk menulis karangan 30 menit, selebihnya digunakan untuk mengoreksi hasil menulis teks deskripsi siswa. Selama siswa mengerjakan tugas, guru sekali-kali berkeliling untuk mengetahui kesungguhan siswa dalam mengerjakan tugas.

Proses pembelajaran itu dapat diketahui melalui dialog berikut ini:

Guru: Silahkan kalian perhatikan gambar media pembelajaran I yang bapak berikan. Tulislah Informasi pada gambar itu ke dalam sebuah teks deskripsi berjudul "Fungsi Pasar bagi Kehidupan Masyarakat". Panjang teks 15 kalimat berdasarkan deskripsi umum dan deskripsi bagian. Teks deskripsi akan dinilai dari segi isi, struktur, dan ejaan. Dapatkah kalian membedakan deskripsi umum dan deskripsi bagian?

Siswa: Dapat pak. Deskripsi umum bagian deskripsi yang mendeskripsikan secara umum, sedangkan deskripsi bagian berisi tentang gambaran-gambaran bagian di dalam teks tersebut.

Guru juga menginformasikan kepada siswa bahwa bagi siswa yang telah selesai boleh dikumpulkan dengan pengawas (guru). Setiap siswa yang menyerahkan tugas, guru mencatat urutan pengumpulan tugas dan waktunya. Waktu yang tersisa dipergunakan guru bersama siswa mengoreksi hasil menulis teks deskripsi salah satu temannya. Berikut ini salah satu hasil menulis teks deskripsi siswa.

Kutipan 1

Lensi Kurniawati VII H

Fungsi Pasar bagi Kehidupan Masyarakat Pasar Kue

Fungsi pasar bagi kehidupan bermasyarakat, misalnya pasar minggu yang ada di bengkulu. Pasar ini berfungsi untuk tempat bertemunya penjual dengan pembeli. Pasar merupakan tempat untuk transaksi ekonomi atau tempat bertukaran barang. Banyak wisatawan yang mengunjungi pasar ini karena pasar ini juga merupakan tempat hiburan. Banyak para wisatawan yang mengunjungi pasar ini karena sangat menyenangkan.

Bagian depan pasar banyak penjual kue misalnya kue lupis, tapai, dan lain-lain, Bagian kiri pasar juga ada penjual martabak. Misalnya martabak kacang dan martabak ketan. Bagian kanan pasar ada penjual es. Misalnya es buah, es cendol, dan es kelapa. Bagian kanan pasar juga banyak penjual ketoprak, bakso, dan masih banyak lagi yang lainnya. Maka dari itu banyak wisatawan yang memanjakan lidah di sana.

Kutipan hasil menulis teks deskripsi tersebut, ditulis oleh guru di papan tulis. Sebagai bahan untuk dianalisis bersama-sama siswa. Adapun hasil analisis kutipan menulis deskripsi tersebut yaitu: Pertama, terdapat kesalahan penulisan ejaan penggunaan huruf kapital (huruf besar). Dalam 
kalimat "Misalnya pasar minggu yang ada di bengkulu". Seharusnya ditulis "Misalnya Pasar Minggu yang ada di Bengkulu". Kedua, terdapat deskripsi umum pada paragraf pertama dan deskripsi bagian pada paragraf kedua yang masih perlu diperbaiki dari kesalahan yang ada.

Selanjutnya guru bersama siswa menyusun kembali kalimat-kalimat dalam sebuah paragraf menjadi teks deskripsi umum dan teks deskripsi bagian. Teks deskripsi umum dan teks deskripsi bagian yang telah diperbaiki dapat dilihat berikut ini:

Kutipan 2

Fungsi Pasar bagi Kehidupan Masyarakat Pasar Minggu

Fungsi pasar bagi kehidupan bermasyarakat, misalnya Pasar Minggu yang ada di Bengkulu. Pasar ini berfungsi untuk tempat bertemunya penjual dengan pembeli. Pasar merupakan tempat untuk transaksi ekonomi atau tempat bertukaran barang. Banyak wisatawan yang mengunjungi pasar ini karena pasar ini juga merupakan tempat hiburan. Banyak para wisatawan yang mengunjungi pasar ini karena sangat menyenangkan.

Bagian depan pasar banyak penjual kue. Misalnya kue lupis, tapai, dan lain-lain, Bagian kiri pasar juga ada penjual martabak. Misalnya martabak kacang dan martabak ketan. Bagian kanan pasar ada penjual es. Misalnya es buah, es cendol, dan es kelapa. Bagian kanan pasar juga banyak penjual ketoprak, bakso, dan masih banyak lagi yang lainnya. Maka dari itu banyak wisatawan yang memanjakan lidah di sana.

Bagian dalam pasar banyak penjual baju yang bercorak batik kain besurek. Ada juga penjual celana levis yang bagus-bagus. Maka dari itu banyak wisatawan yang membeli baju dan celana di sana. Mereka merasa senang karena telah mengunjungi Pasar Minggu yang terletak di jantung Kota Bengkulu.
Guru juga menjelaskan struktur teks deskripsi dalam menulis teks deskripsi. Yaitu deskripsi umum dan deskripsi bagian. Penjelasan guru tersebut dapat dilihat dalam sebuah dialog berikut ini:

Guru :"Apakah teks deskripsi tersebut sudah memiliki struktur teks deskripsi. Yaitu deskripsi umum dan deskripsi bagian?"

Siswa :"Sudah" ada yang mengatakan "belum".

Guru : :"Ya, teks deskripsi itu sudah boleh dikatakan memiliki struktur deskripsi umum pada paragraf pertama, sedangkan paragraf kedua dan ketiga merupakan deskripsi bagian."

c. Tahap Observasi Siklus I

Pada tahap observasi guru bersama kolaborator mengamati kegiatan-kegiatan yang dilakukan siswa selama proses kegiatan pembelajaran berlangsung. Adapun kegiatan-kegiatan siswa yang diamati: Pertama, aktivitas siswa selama kegiatan pembelajaran berlangsung. Kedua, kooperatif siswa dalam mengerjakan tugas.

Pada tahap ini ditemukan masalah sebagai berikut: (1) Dalam mengumpulkan tugas, siswa masih ada yang tidak tepat waktu; (2) Aktivitas siswa dan kooperatif siswa dalam kelas masih rendah; (3) Siswa masih dangkal dalam mengembangkan data menjadi teks deskripsi umum dan deskripsi bagian; (4) Siswa masih banyak menulis kesalahan penggunaan ejaan.

Faktor yang diduga menjadi timbulnya masalah tersebut adalah: (1) Siswa tidak terbiasa membuat langkahlangkah pengembangan data atau kerangka menulis deskripsi; (2) Siswa belum dapat membedakan deskripsi umum dan deskripsi bagian dalam 
struktur teks deskripsi; (3) Siswa belum banyak menguasai penggunaan ejaan yang benar.

Hasil observasi yang dilaksanakan pada siklus I adalah: (1) Aktivitas siswa yang memperoleh nilai baik sekali 2 siswa, yang mendapat nilai baik 3 siswa, yang mendapat nilai cukup 15 siswa, dan yang memperoleh nilai kurang 3 siswa; (2) Keterampilan kooperatif yang mendapat nilai baik 6 siswa, mendapat nilai cukup 10 siswa, dan nilai kurang 7 siswa.

d. Tahap Refleksi Tindakan Siklus I

Peneliti mendiskusikan hasil pengamatan yang dilakukan oleh mitra kolaborasi dalam proses tindakan yang digunakan secara jelas dan lengkap ke dalam lembar pengamatan, melakukan observasi terhadap pengalaman selama proses tindakan berlangsung didukung dengan hasil dialog dengan mitra kolaborasi (observer).

Hasil refleksi yaitu berupa temuan tingkat keefektifan desain pembelajaran dengan menggunakan media gambar bersambung dan daftar permasalahan yang muncul di lapangan. Selama pelaksanaan kegiatan pembelajaran pada siklus I, masih terdapat beberapa siswa yang (1) kurang aktif dalam memperhatikan penjelasan guru, (2) kurang memperhatikan media gambar yang disajikan oleh guru, sehingga pada saat pelaksanaan tes menulis teks deskripsi pada siklus I belum berhasil.

Tindakan siklus I dianggap belum berhasil karena dilihat dari kemampuan siswa dalam mengerjakan tugas, aktivitas siswa selama kegiatan pembelajaran berlangsung, kooperatif siswa dalam kegiatan pembelajaran masih sangat kurang.
Jika hasil menulis karangan deskripsi tersebut dilihat dari aspek penilaian Isi, Siswa baru mampu menulis teks deskripsi yang panjangnya 9 kalimat. Hal ini berarti siswa belum mampu menulis teks deskripsi yang panjangnya 12-15 kalimat.

Dari hasil menulis teks deskripsi di atas, secara keseluruhan aspek yang dinilai masih perlu perbaikan. Jadi, perlu dilanjutkan pada siklus berikutnya.

2) Deskripsi Data Siklus II

a. Tahap Perencanaan Siklus II

Bertumpu dari masalah yang ditemukan pada tindakan I, guru merencanakan tindakan selanjutnya, pembelajaran tindakan II ini untuk mempertajam serta mempertingi pencapaian indikator yang ditentukan. Tindakan II ini difokuskan pada pembelajaran kemampuan menulis teks deskripsi yang panjangnya sekitar 12-15 kalimat.

Penggunaan media gambar bersambung bertemakan "Fungsi Pasar bagi Kehidupan Masyarakat" pada tindakan I, belum seluruhnya mampu meningkatkan kemampuan menulis teks deskripsi. Untuk itu, guru merencanakan media gambar bersambung yang temanya sama, yaitu "Fungsi Pasar bagi Kehidupan Bermasyarakat" untuk memperkaya wawasan siswa. Sehingga kemampuan menulis teks deskripsi yang panjangnya sekitar 12-15 kalimat tercapai oleh siswa. Rencana guru mendapat tanggapan dari kolaborator. Dialog guru dengan kolaborator adalah sebagai berikut:

Guru $\quad$ :Bagaimana menurut Bapak media gambar bersambung kita pilih temanya yang sama, yaitu "Fungsi Pasar bagi Kehidupan Masyarakat" Untuk memperkaya wawasan siswa. 
Kolaborator:"Saya, setuju. Bagaimana langkahlangkah penyajian pada siklus II nanti?"

Guru :Seperti siklus sebelumnya, guru menentukan kelompok, guru membagikan gambar, siswa berdiskusi sambil memperhatikan gambar, guru menugaska siswa membuat kerangka menulis teks deskripsi, siswa membacakan hasilnya.

b. Tahap Pelaksanaan Siklus II

Seperti halnya dengan tindakan sebelumnya, tindakan siklus II dibagi menjadi dua pertemuan, dengan menitik beratkan pada pembelajaran kemampuan menulis teks deskripsi yang panjangnya sekitar 12-15 kalimat.

1) Pertemuan Pertama ( $2 \times 40$ menit) Guru menunjukkan gambar bersambung sebagai media pembelajaran dengan tema "Fungsi Pasar bagi Kehidupan Masyarakat". Guru menyuruh siswa membentuk kelompok. Guru membagikan gambar bersambung kepada masing-masing kelompok. Guru menyuruh siswa mengamati gambar bersambung yang mereka terima. Guru menyuruh siswa memaparkan hasil diskusinya di depan kelas masing-masing kelompok. Siswa beserta guru mengomentari hasil masing-masing kelompok. Selama kegiatan belajarmengajar guru dibantu kolaborator untuk mencatat aktivitas dan sikap kooperatif siswa. Akhir dari pembelajaran, guru menutup pembelajaran dan siswa mengucapkan terima kasih.

2) Pertemuan Kedua ( $3 \times 40$ menit)

Sebelum melaksanakan tes, guru beserta siswa membahas hasil pekerjaan dengan beberapa paragraf yang di dalamnya ada beberapa kalimat. Guru menyuruh beberapa siswa untuk menulis di papan tulis. Guru bersama siswa memperbaiki atau menanggapi hasilnya. Waktu yang disediakan 20 menit. Selanjutnya, guru merevisi hasil menulis teks deskripsi siswa yang kurang tepat penggunaan ejaan pada tes siklus I. Waktu yang disediakan 20 menit. Setelah itu guru mengadakan tes tindakan siklus II. Waktu yang disediakan untuk tes adalah 30 menit. Pada akhir pembelajaran, guru bersama siswa melakukan refleksi hasil pembelajaran.

c. Tahap Observasi Siklus II

Pada tahap observasi guru bersama kolaborator mengamati kegiatan-kegiatan yang dilakukan siswa selama proses kegiatan pembelajaran berlangsung. Adapun kegiatan-kegiatan siswa yang diamati: Pertama, aktivitas siswa selama kegiatan pembelajaran berlangsung. Kedua, kooperatif siswa dalam mengerjakan tugas.

Hasil observasi yang dilaksanakan pada siklus II adalah (1) Aktivitas siswa yang mendapat nilai baik sekali 3 siswa dan nilai baik 13 siswa, mendapat nilai cukup 6 siswa, sedangkan mendapat nilai kurang 1 siswa. (2) Sikap kooperatif siswa pada tindakan II yang mendapat nilai baik sekali 3 siswa, mendapat nilai baik 13, dan mendapat nilai cukup 6 siswa, sedangkan mendapat nilai kurang 1 siswa. (3) Siswa mengumpulkan tugas tepat waktu 15 siswa, sedangkan yang tidak tepat waktu 8 siswa.

d. Tahap Refleksi Siklus II

Peneliti mendiskusikan hasil pengamatan yang dilakukan oleh mitra kolaborasi dalam proses tindakan yang digunakan secara jelas dan lengkap ke dalam lembar pengamatan, melakukan observasi terhadap pengalaman selama proses tindakan berlangsung didukung dengan hasil dialog dengan mitra kolaborasi (observer). 
Hasil refleksi yaitu berupa temuan tingkat keefektifan desain pembelajaran dengan menggunakan media gambar bersambung dan daftar permasalahan yang muncul di lapangan digunakan kembali ke dalam rancangan tindakan berikutnya, selanjutnya tindakan refleksi terhadap rancangan yang telah disusun, diperbaiki kembali sebelum digunakan dalam siklus berikutnya.

Tindakan siklus II belum mencapai keberhasilan karena dilihat dari kemampuan siswa dalam mengerjakan tugas, aktivitas siswa selama kegiatan pembelajaran berlangsung, kooperatif siswa dalam kegiatan masih rendah.

Dari hasil menulis teks deskripsi di atas, secara keseluruhan aspek yang dinilai belum terjadinya indikator keberhasilan. Jadi, perlu dilanjutkan pada siklus berikutnya untuk perbaikan dan peningkatan.

3) Deskripsi Data Siklus III

a. Tahap Perencanaan Siklus III

Bertitik tolok dari masalah yang ditemukan pada tindakan II, guru merencanakan tindakan selanjutnya, pembelajaran tindakan III ini untuk mempertajam serta meningkatkan pencapaian indikator yang ditentukan. Tindakan III ini difokuskan pada pembelajaran ejaan. Yaitu kata penghubung, kata depan, dan awalan dalam menulis teks deskripsi.

Penggunaan media gambar bersambung bertemakan "Fungsi Pasar bagi Kehidupan Masyarakat" pada tindakan II, belum seluruhnya mampu meningkatkan kualitas menulis teks deskripsi dengan menggunakan kata penghubung, kata depan, dan awalan. Untuk itu, guru merencanakan menambah media gambar bersambung yang temanya sama, tetapi lebih mempertajam pada struktur deskripsi bagian. Rencana guru mendapat tanggapan dari kolaborator.

b. Tahap Pelaksanaan Siklus III

Sama halnya dengan tindakan sebelumnya, tindakan siklus III dibagi menjadi dua pertemuan, dengan menitik beratkan pada penggunaan kata penghubung, kata depan dan awalan.

1) Pertemuan Pertama ( $2 \times 40$ menit)

Guru menunjukkan gambar bersambung sebagai media pembelajaran dengan tema "Fungsi Pasar bagi Kehidupan Masyarakat". Gambar bersambung ini lebih tajam mengarah pada struktur deskripsi bagian. Guru menyuruh siswa mengamati gambar bersambung yang telah dibagikan pada kelompok masingmasing. Guru menyuruh siswa memaparkan hasil diskusinya di depan kelas masing-masing kelompok. Siswa beserta guru mengomentari hasil menulis teks deskripsi masing-masing kelompok. Selama kegiatan belajarmengajar guru dibantu kolaborator untuk mencatat aktivitas dan sikap kooperatif siswa. Akhir dari pembelajaran, guru menutup pembelajaran dan siswa mengucapkan terima kasih.

2) Pertemuan Kedua ( $3 \times 40$ menit)

Sebelum melaksanakan tes, guru beserta siswa membahas hasil menulis teks deskripsi yang di dalamnya ada kata penghubung, kata depan, dan awalan. Siswa diminta menunjukkan kata-kata tersebut. Guru menyuruh beberapa siswa untuk menuliskan di papan tulis. Guru bersama siswa memperbaiki atau menanggapi hasilnya. Waktu yang disediakan 20 menit. Selanjutnya, guru merevisi hasil menulis teks deskripsi siswa yang kurang tepat menuliskan 
ejaan. Yaitu kata hubung, kata depan, dan awalan pada tes siklus II. Waktu yang disediakan 20 menit. Setelah itu guru mengadakan tes tindakan siklus III. Waktu yang disediakan untuk tes adalah 30 menit. Pada akhir pembelajaran, guru bersama siswa melakukan refleksi hasil pembelajaran.

\section{c. Tahap Observasi Siklus III}

Hasil observasi yang dilaksanakan pada siklus III adalah (1) Aktivitas siswa yang mendapat nilai baik sekali 6 siswa dan nilai baik 15 siswa, mendapat nilai cukup 2 siswa, sedangkan mendapat nilai kurang tidak ada. (2) Sikap kooperatif siswa pada tindakan III yang mendapat nilai baik sekali 6 siswa, mendapat nilai baik 15, dan mendapat nilai cukup 2 siswa, sedangkan mendapat nilai kurang tidak ada. (3) Siswa mengumpulkan tugas tepat waktu 20 siswa, sedangkan yang tidak tepat waktu 3 siswa.

d. Tahap Refleksi Siklus III

Peneliti mendiskusikan hasil pengamatan yang dilakukan oleh mitra kolaborasi dalam proses tindakan yang digunakan secara jelas dan lengkap ke dalam lembar pengamatan, melakukan observasi terhadap pengalaman selama proses tindakan berlangsung didukung dengan hasil dialog dengan mitra kolaborasi (observer).

Hasil refleksi yaitu berupa temuan tingkat keefektifan desain pembelajaran dengan menggunakan media gambar bersambung dan daftar permasalahan yang muncul di lapangan digunakan kembali ke dalam rancangan tindakan berikutnya.

Kesimpulan hasil refleksi antara peneliti dan observer yang berupa temuan peningkatan kemampuan menulis teks deskripsi dengan media gambar bersambung.

\section{SIMPULAN}

Berdasarkan hasil penelitian dan pembahasan dapat disimpulkan bahwa ada peningkatan kemampuan menulis teks deskripsi siswa kelas VII SMP Negeri 19 Kota Bengkulu dengan media gambar bersambung. Peningkatan kemampuan menulis teks deskripsi tersebut dilihat dari skor rata-rata yang diperoleh siswa pada siklus I sebesar 70 kategori cukup dan meningkat pada siklus II dengan skor rata-rata sebesar 76,04 kategori baik (meningkat sebesar 6,04), selanjutnya pada siklus III juga meningkat dengan skor rata-rata 86,17 kategori baik sekali (meningkat sebesar 10,13).

\section{Daftar Pustaka}

Anitah, Sri. 2008. Media Pembelajaran. Surakarta: LPP UNS.

Arikunto, Suharsimi. 2010. Prosedur Penelitian, Suatu Pendekatan Praktik. Jakarta: Rineka Cipta.

Arsyad, Azhar. 2014. Media Pembelajaran. Jakarta: Rajawali Pers.

Asyhar, Rayandra. 2011. Kreatif Mengembangkan Media Pembelajaran. Jakarta: Gaung Persada.

Hafni. 1985. Media Pengajaran Bahasa Yang Efektif. Jakarta: P2LPTK.

Haryanto, Deri. 2013. Peningkatan Kemampuan Menulis Karangan Deskripsi Siswa Kelas IX SMP Negeri 01 Lebong Selatan dengan Media Gambar. Bengkulu: Tak terpublikasikan. 
Mahsun. 2014. Teks dalam Pembelajaran Bahasa Indonesia. Jakarta: Rajawali Pers.

Munadi. 2008. Media Pembelajaran Sebuah Pendekatan Baru. Cipayung: Gaung Persada.

Muslich, Masnur. 2009. Melaksanakan PTK itu mudah. Malang: Bumi Aksara.

Nurgiyantoro. 1995. Penelitian dalam Pengajaran Bahasa dan Sastra. Yogyakarta: BPFE.

Rohani, Ahmad. 1997. Media Instruksional Edukatif. Jakarta: Rineka Cipta.

Rustono. 2014.Bahasa Indonesia Wahana Pengetahuan. Jakarta: Kemdikbud.

Sanaky, Hujair. 2011. Media Pembelajaran. Yogyakarta: Kaukaba Dipantara.

Sanjaya, Wina. 2013. Penelitian Tindakan Kelas. Jakarta: Prenadamedia Group.

Sawali dan Wahono. 2013. Mahir Berbahasa Indonesia. Jakarta: Erlangga.
Sunarti dan Selly Rahmawati.2014. Penilaian dalam Kurikulum 2013. Yogyakarta: Andi Offset.

Susetyo. 2009. Menulis Akademik. Bengkulu: Unit Penerbitana FKIP UNIB.

Susetyo. 2010. Penelitian Kuantitatif dan Penelitian Tindakan Kelas. Bengkulu: FKIP UNIB.

Tampubolon, Saur. 2014. Penelitian Tindakan Kelas Sebagai Pengembangan Profesi Pendidik dan Keilmuan. Jakarta: Penerbit Erlangga.

Taniredja, Tukiran dkk. 2010. Penelitian Tindakan Kelas Untuk Pengembangan Profesi Guru Praktik, Praktis dan Mudah. Bandung: Alfabeta.

Tarigan, Harry Guntur. 2008. Menulis Sebagai Suatu Keterampilan Berbahasa. Bandung: Percetakan Angkasa. 